\title{
Erratum to: On the return period of the 2003 heat wave
}

\section{Arthur Charpentier}

Published online: 30 September 2011

(C) Springer Science+Business Media B.V. 2011

\section{Erratum to: Climatic Change DOI 10.1007/s10584-010-9944-0}

In my article, On the return period of the 2003 heat wave, the sentence "summer of 2003 was by far the hottest summer since 1500" is wrongly attributed to "Luterbacher et al. (2003)'. My probable intent was to cite Casty et al. (2005) which actually states "the years 1994, 2000, 2002 and particularly 2003 were the warmest since 1500". Note that a similar statement can also be found in Stott et al. (2004), "The summer of 2003 was probably the hottest in Europe since at latest ad 1500".

Regarding the statement (in reference to Luterbacher et al., which was actually published in 2004) that "their estimate of the return period of that event is 250 years", the attribution again is incorrect. Such an estimate can be found in Brown et al. (2005), "best estimate of a 1 in 250 year event" or Lowe et al. (2004) "the same event is likely to occur much more frequently; most likely, once every 250 years", among others.

I regret these inappropriate attributions and inadequate referencing.

\section{References}

Brown S, Stott P, Clark R, Temperature Extremes (2011) the Past and the Future. Hadley Centre for Climate Prediction and Research Working Paper. [online http://stabilisation.metoffice.com/posters/Brown_Simon.pdf]

Casty C, Wanner H, Luterbacher J, Esper J, Böhm R (2005) Temperature and precipitation variability in the European Alps since 1500. Int J Climatol 25(14):1855-1880, 30 November 2005

Lowe J, Smith F, Jenkins G, Pope V (2004) Uncertainty, risk and dangerous climate change. Hadley Centre [online http://cedadocs.badc.rl.ac.uk/247/

Luterbacher J, Dietrich D, Xoplaki E, Grosjean M, Wanner H (2004) European seasonal and annual temperature variability, trends, and extremes since 1500. Science 303:1499-1503

Stott PA, Stone DA, Allen MR (2004) Human contribution to the European heatwave of 2003. Nature 432:610-614 (2 December 2004)

The online version of the original article can be found at http://dx.doi.org/10.1007/s10584-010-9944-0.

A. Charpentier $(\square)$

Université Rennes 1, CREM-CREST, 7 place Hoche, 35000 Rennes, France

e-mail: arthur.charpentier@univ-rennes1.fr

A. Charpentier

École Polytechnique, 91128 Palaiseau, cedex, France 